\title{
AGATA ULANOWSKA* \\ BUT HOW WERE THEY MADE? MORE ABOUT PATTERNED TEXTILES IN THE AEGEAN BRONZE AGE
}

\begin{abstract}
This paper scrutinises the iconography of patterned textiles in Bronze Age Greece as a potential source of technical knowledge of the patterning and weaving techniques. The variety of patterns on costumes depicted in Xeste 3, Akrotiri, Thera is a case study, examined in close relation to the textile technology available at the time, evidence of archaeological textiles from Greece and Akrotiri, and experimental reconstructions of the depicted patterns in weaving. By analysing several specific features of the painted and woven patterns, a critical overview of the possible techniques of manufacturing patterned textiles is presented. It is argued that there is little possibility of identifying a specific technique of patterning or weaving, on the basis of the Aegean iconography. However, specific features of the painted patterns seem to imitate in a great detail the appearance of the woven patterns. Therefore, it is argued that the wall painters were generally aware of the technical details of actual textiles and that it was important for them to attain a veracity in the rendering of the patterns.
\end{abstract}

Keywords: textile production, iconography of textiles, patterned textiles, Akrotiri, Bronze Age Greece, experimental archaeology

\section{Introduction ${ }^{1}$}

Patterned textiles or, in fact, decorated textiles, are barely represented in the limited corpus of archaeological textiles from Bronze Age Greece. ${ }^{2}$ However, there is a variety of patterned fabrics attested by the abundant iconography of textiles and clothing in various media of Aegean art. This indirect evidence, represented on figurines, murals and possibly also on pottery, demonstrates the diversity of patterns, ranging from simple, single-colour stripes to the most complex, multi-coloured, interlocked-patterns and floral or marine-style designs. ${ }^{3}$

The visually attractive depictions of Minoan and Mycenaean costumes, as well as textile-like painted floors of Mycenaean palaces, have attracted scholarly attention since the

\footnotetext{
* Institute of Archaeology, University of Warsaw; (D) https:// orcid.org/0000-0002-4946-2711; a.ulanowska@uw.edu.pl

${ }^{1}$ The research underlying this paper was undertaken within my FUGA internship grant at the Centre for Research on Ancient Technologies of the Institute of Archaeology and Ethnology, Polish Academy of Sciences, awarded by the National Science Centre in Poland (DEC-2015/16/S/HS3/00085) in years 2015-2017.

I would like to express my thanks to Paul Barford and Jennifer Wilson for improving my English.

${ }^{2}$ For an archaeological find of decorated textile from Akrotiri, Thera, see Moulhérat and Spantidaki 2007; Spantidaki and Moulherat 2012, 187-188.

${ }^{3}$ For a brief outline of the iconographic evidence and research methodologies, see Chapin 2016.
}

moment of their discovery. ${ }^{4}$ Elaborate patterns and costumes, as well as the possible visual impact of Aegean textiles on the painted decoration of Egyptian tomb ceilings ${ }^{5}$ has provided the basis for the assumption that Aegean patterned textiles were technically superior and attractive trade goods.

In recent years, with the significant development of textile research, ${ }^{6}$ the key importance of textile production in Bronze Age economies has been recognised more clearly. ${ }^{7}$ Fine patterned fabrics are considered as elite textiles that expressed high social status and the prestige of their wearers, or their specific (e.g. priestly) function. ${ }^{8}$ The significant economic value of patterned textiles ${ }^{9}$ must have resulted from the large workloads and advanced knowledge and skills required to produce such fabrics, as well as from the exploitation of exclusive dyes, such as murex purple, and, perhaps, exclusive raw materials, such as wild silk and sea silk. ${ }^{10}$

${ }^{4}$ Cf. Hackl 1912; Evans 1921-1935; Wace 1927.

${ }^{5}$ Cf. Kantor 1947; Barber 2016.

${ }^{6}$ For an overview of recent developments in textile research, see Rahmstorf 2015; Siennicka et al. 2018.

${ }^{7}$ Cf. Gillis and Nosch 2007; Burke 2010; Nosch and Laffineur 2012; Breniquet and Michel 2014; Andersson Strand and Nosch 2015.

${ }^{8}$ Cf. Barber 1991; Jones 2015; Peterson Murray 2016.

${ }^{9}$ For parameters forming the economic value of textiles see Jarva and Lipkin 2014.

${ }^{10} \mathrm{For}$ an overview of the purple-dye industry and the possible use of sea silk in the Aegean Bronze Age see Burke 2012 and various 
The iconography of Aegean textiles and cloths has also been successfully re-approached. By integrating available iconographic records with evidence of archaeological textiles, textile tools, dyes and dye-works, the iconography of textiles has been investigated as a potential source of knowledge about raw materials, weaving techniques, dyes, crosscraft interactions and clothing culture. ${ }^{11}$ Finally, textile patterns have become an inspiration for several experimental reconstructions of costumes and accessories, ${ }^{12}$ and weaves. ${ }^{13}$

In this paper, the imagery of patterned textiles is re-examined in close relation to textile technology in Bronze Age Greece, taking patterned costumes depicted on murals in Xeste 3, Akrotiri, Thera ${ }^{14}$ as a case study. Based on an examination of actual textile remains, textile techniques and tools that were available at the time, a critical overview of possible techniques of manufacture of patterned textiles is discussed. Several apparent ambiguities or discrepancies between the iconography of textiles and the present knowledge of textile technology are also outlined. ${ }^{15}$ While discussing these problems, the paper also attempts to delimit the reliability of experimental reconstructions of textile techniques that are inspired by depictions of patterned textiles in art.

\section{On the reliability of the Aegean iconography of patterned textiles}

For the majority of textile scholars, the iconography of patterned textiles in Bronze Age Greece, especially the ones that are depicted as garments or household and maritime textiles is largely reliable, even if the specific techniques of patterning cannot be suggested with ease. ${ }^{16}$ The assumed accuracy with which textile patterns were rendered in art may be explained by the general naturalistic tendencies of Aegean art, ${ }^{17}$ observed e.g. in the manner of depicting human figures, differentiated by gender and age in Minoan wall paintings and ivory sculpture. ${ }^{18}$

Further arguments for the veracity of depictions of the patterned textiles may be drawn from the socially-visible nature

contributions in Landenius Enegren and Meo 2017. On the use of wild silk see Panagiotakopulu et al. 1997; Van Damme 2012.

${ }^{11} \mathrm{Cf}$. Harris 2012; various contributions in Nosch and Laffineur 2012; Nosch 2015; Nosch 2016; Shaw and Chapin 2016; Ulanowska 2018a.

${ }^{12}$ Lillethun 2003; Lillethun 2012; Jones 2015.

${ }^{13}$ Spantidaki 2008; Hoskins 2015a; Hoskins 2015b; Jones 2015; Ulanowska 2018a, 251-253.

${ }^{14}$ Doumas 1992, 127-175, Pls. 100-109, 116-126, 129-130, 133-134.

${ }^{15}$ Some of the research problems discussed in this paper have briefly been outlined by me in a poster presented at the XIII ${ }^{\text {th }}$ North European Symposium for Archaeological Textiles in Liberec, 2017, cf. Bravermanová et al. 2017, dvd with posters attached to the volume.

${ }^{16}$ Carington Smith 1975, 305-326, 469-461; Barber 1991, 314-330; Tzachili 1997, 224-248; Marcar 2004, 229-230; Jones 2015; Shaw and Chapin 2016.

${ }^{17}$ On an overview of research methodologies, see Chapin 2016.

${ }^{18}$ Cf. Immerwhar 1990; McGillivray et al. 2000; Sackett 2006; Chapin 2007; Chapin 2009. of the textile craft. While being complex and diversified, labour-intensive and time-consuming, textile manufacture should be seen as a social practice. In Bronze Age Greece, the location of weaving (attested by the presence of loom weights), was regularly organised alongside other crafts both in a household and specialised mode of production. ${ }^{19}$ Therefore, some basic knowledge of weaving technology may have been shared by a large part of the society and wall painters may also have been generally aware of how textiles were structured and woven. Furthermore, several cross-craft interactions have been observed between the arts of wall painting and textile making. ${ }^{20}$ Techniques of production of certain pigments and textiles dyes, such as murex purple and, possibly, indigo were very probably shared. ${ }^{21}$ Moreover, murex-shells were recycled to produce lime putty and plaster for frescoes. ${ }^{22}$

On the conceptual level of designing fabrics and paintings, the concept of a pattern repeat, i.e. a repetitive unit of complex design that enables accurate rendering of the entire design composed of continuous or expanding elements, may have been shared. ${ }^{23}$ In weaving, a pattern repeat or rapport is technically built into the structure of the fabric..$^{24}$ According to the weaving technique, the pattern has either to be planned before warping and setting up a loom is commenced (e.g. for checker or chevron and lozenge twill patterns) or it can be built into the structure of the fabric while weaving (e.g. patterns in warp or weft floats and supplemental weft technique). In wall and floor painting, a similar concept seems to stand behind the use of an artist's grid that was incised in the plaster in order to facilitate rendering complicated patterns comprised of scales, tri-curved arches, rosettes, quatrefoils, etc. ${ }^{25}$

However, the Aegean wall paintings represented also several mythical or fantastic creatures, such as griffins ${ }^{26}$ or daemons. ${ }^{27}$ Floors from the palace at Pylos integrated textile patterns with stone imitations creating hybrids of a symbolic meaning. ${ }^{28}$ Therefore, some textile patterns, e.g. the most complex ones, may have also been intended to show 'mythical-quality' fabrics worn by supernatural beings,

${ }^{19}$ Cf. Andersson Strand and Nosch 2015; Ulanowska 2018a, 245-247; Ulanowska and Siennicka, forthcoming.

${ }^{20}$ For an outline of possible interrelations between weavers and mural painters see Blakolmer 2012; Ulanowska 2018a.

${ }^{21}$ Aloupi et al. 2000; Brysbaert et al. 2006; Brysbaert 2007; Brysbaert 2008.

${ }^{22}$ Brysbaert 2007.

${ }^{23}$ Ulanowska 2018a.

${ }^{24}$ Cf. Burnham 1964, 108-109.

${ }^{25} \mathrm{Cf}$. Egan 2016; Shaw 2016.

${ }^{26}$ For example griffins in the Room of the Throne, palace at Knossos: Evans 1935, 910-913, Pl. XXXII; Throne Room fresco at Pylos, griffins and lions frieze from Hall 64, Pylos: Lang 1969, 110-111, 154, Pls. 53, 54, 134, 20 abc C 6; or a griffin flanking a goddess on the North Wall of Room 3a, Xeste 3, Akrotiri: Doumas 1992, 131-132, 158-159; Pls. 122, 128, 165.

${ }^{27}$ For example daemons pulling or carrying a rope from the Cult Centre at Mycenae, Kritseli-Providi 1982, 21-28, A1-5, Figs. 2-3, Pl. 1.

${ }^{28}$ Egan 2016, 142. 
of a structure and complexity that was beyond knowledge and skills of the Bronze Age Aegean weavers. Additionally, several depictions of Minoan-style female costumes in the Mycenaean palaces of Mainland Greece have been viewed as iconographic conventions adopted to represent the traditional dress rather than pictures of actual textiles and attires ${ }^{29}$ and thus specific weaves or finishing techniques.

\section{Patterned textiles from Xeste 3, Akrotiri as a case study}

From the panoply of costumes shown on the wall paintings at Akrotiri, Thera, patterned textiles are predominantly represented in the three-storey public building Xeste 3. Here, a complex iconographic programme of wall paintings illustrating multiple religious activities has been partially restored. ${ }^{30}$ One of the themes, illustrated by scenes of gathering and offering crocus flowers to the enthroned goddess ('Mistress of the Animals'), may even have references to textile manufacture and the use of saffron as a textile dye. ${ }^{31}$

Patterned textiles are worn by three Adorants from the North Wall of the Lustral Basin, Room 3a, ground floor, ${ }^{32}$ two Saffron Gatherers from the East Wall, Room 3a, first floor, ${ }^{33}$ the 'Mistress of the Animals' and two Saffron Gatherers from the North Wall, Room3a, first floor, ${ }^{34}$ and Mature Women in a Procession from Room 3b, first floor. ${ }^{35}$ Finally, a patterned textile or garment is carried as an offering by a young male from Room 3b, ground floor ${ }^{36}$ - cf. Table 1.

To the eye of the textile scholar, such as E. Barber, many of these patterned textiles, in contrast to the most elaborate and complex patterns from the palaces and villas in Crete and the Mainland, "look readily - even easily - weavable" and form a technically consistent group of fabrics. ${ }^{37}$ Indeed, several specific techniques of patterning or finishing, such as supplemental warp-float ${ }^{38}$ and tablet weaving for making bands, ${ }^{39}$ and weft-faced weave, ${ }^{40}$ supplemental weft-float (continuous or discontinuous) or compound-weave or double weave, ${ }^{41}$ embroidery, ${ }^{42}$ tapestry,${ }^{43}$ and twills ${ }^{44}$ for making larger fabrics, have already been suggested as plausible to

\footnotetext{
${ }^{29}$ Cf. Peterson Murray 2016, 81-89.

${ }^{30} \mathrm{Cf}$. Doumas 1992; Chapin 1997-2000; Rehak 2002; Marinatos 2015, especially 98-125; Peterson Murray 2016, 63-75.

${ }^{31}$ Cf. Douskos 1980, 120; Barber 1994, 114-116; Peterson Murray 2016, 69.

${ }^{32}$ Doumas 1992, 129-130, Pls. 100-108.

${ }^{33}$ Doumas 1992, 130, Pls. 122-124.

${ }^{34}$ Doumas 1992, 130-131, Pls. 122-126, 129-130.

${ }^{35}$ Doumas 1992, 131, Pls. 131-134; Chapin 2008.

${ }^{36}$ Doumas 1992, 130, Pls. 109, 113.

${ }^{37}$ Barber 1991, 316-318, see 317 for the quotation.

${ }^{38}$ Barber 1991, 317.

${ }^{39}$ Spantidaki 2008, 45-46.

${ }^{40}$ Hoskins 2015a, 21-22.

${ }^{41}$ Barber 1991, 317; Spantidaki 2008, 44-45; Jones 2015.

${ }^{42}$ Barber 1991, 317.

${ }^{43}$ Cf. Barber 1991, 317, 320-321.

${ }^{44}$ Lillethun 2003, 465; Spantidaki 2008, 45.
}

produce textiles of the appearance similar to that of the paintings (Table 1). Additionally, a special treatment of a woven fabric, e.g. moisturising linen with oil has been suggested to explain the diaphanous appearance of garments worn by the Adorants. ${ }^{45}$

A few of the suggested techniques have already been used to weave pieces of patterned fabrics that imitated the appearance of the painted patterns, ${ }^{46}$ such as:

- a tablet-woven reconstruction of a crocus border on the Mistress of Animals' blouse or chemise (double-faced weave and broché); ${ }^{47}$

- ribbed tabby reconstructions of the striped borders of the Saffron Gatherers' blouses or chemises (no information about the loom); ${ }^{48}$

- reconstructions of lozenges on the Saffron Gatherers' blouses or chemises: warp-weighted loom-woven lozenges in twill and lozenges in supplemental weft; 49

- reconstructions of various patterns on the Saffron Gatherers' and Adorants' costumes in weft-faced weave (lozenges with various fillers, continuous patterns of forked crisscrosses, zigzags, zigzags and dots, zigzags and stripes, yo-yo; no information about the loom). ${ }^{50}$

Specific features of the costumes, such as borders or trimmings finished by elaborate tassels have been explained in terms of the warp-weighted loom technology and interpreted as starting borders, ${ }^{51}$ that is the borders that are woven or plaited separately as beginnings for large fabrics to be woven on the warp-weighted loom. ${ }^{52}$

The main aim of these experiments was to ascertain the possibility of creating fabrics, using raw materials and techniques potentially available to the Bronze Age weavers from Akrotiri, similar to those represented on frescoes.

However, the more complex patterns, e.g. the patterns on the garments of the Mature Women in the Procession, especially the skirt of the Lady of the Landscape showing birds in a rocky landscape, ${ }^{53}$ cannot be so easily explained in terms of weaving technology available at the time (cf. Table 1). Therefore, it has also been debated whether some of the textile patterns may have been a painters' creation or, whether the patterns on the textile themselves may have been painted, not woven. ${ }^{54}$

${ }^{45}$ Cf. Jones 2003, 441-443, Pls. LXXXIV:c, d.

${ }^{46} \mathrm{On}$ differences between replication, re-creation and reconstruction of textiles in experimental archaeology, see Barber 2003.

${ }^{47}$ Spantidaki 2008.

${ }^{48}$ Jones 2015, 81, 85, 87, Fig. 4.54, 4.65.

${ }^{49}$ Spantidaki 2008.

${ }^{50}$ Hoskins 2015a.

${ }^{51}$ Cf. Barber 1991, 336; Jones 2015, 67-69.

${ }^{52} \mathrm{Cf}$. Ulanowska 2018 b.

${ }^{53} \mathrm{Cf}$. Chapin 2008; Peterson Murray 2016, 70

${ }^{54}$ Cf. Barber 1991, 321; Marcar 2004, 227 


\begin{tabular}{|c|c|c|c|c|c|c|}
\hline $\begin{array}{l}\text { TYPE } \\
\text { OF PATTERNED } \\
\text { TEXTILE }\end{array}$ & Fresco & $\begin{array}{l}\text { SUGGESTED TEXTILE } \\
\text { TECHNIQUE } \\
\text { (after Barber 1991; } \\
\text { Spantidaki 2008; } \\
\text { Jones 2013; } \\
\text { Jones 2015; } \\
\text { Hoskins 2015a } \\
\text { and the author) }\end{array}$ & $\begin{array}{l}\text { SUGGESTED TYPE } \\
\text { OF A LOOM } \\
\text { Types of looms } \\
\text { attested by archae- } \\
\text { ological evidence } \\
\text { from Bronze Age } \\
\text { Greece are marked } \\
\text { in bold }\end{array}$ & $\begin{array}{l}\text { POSSIBLE } \\
\text { ANALOGIES } \\
\text { IN ARCHAE- } \\
\text { OLOGICAL } \\
\text { FINDS OF } \\
\text { TEXTILES } \\
\text { FROM } \\
\text { BRONZE } \\
\text { AGE } \\
\text { GREECE } \\
\text { (after Span- } \\
\text { tidaki and } \\
\text { Moulherat } \\
\text { 2012; Skals } \\
\text { et al. 2015) }\end{array}$ & $\begin{array}{l}\text { POSSIBLE ANALOGIES } \\
\text { IN ARCHAEOLOGICAL } \\
\text { FINDS OF BRONZE } \\
\text { AGE TEXTILE FROM } \\
\text { EUROPE AND THE } \\
\text { MEDITERRANEAN } \\
\text { (after Barber 1991; } \\
\text { Vogelsang-Eastwood } \\
\text { 1999; James et al. } \\
\text { 2009; Gleba and } \\
\text { Mannering 2012; } \\
\text { Grömer et al. 2013; } \\
\text { Skals et al. 2015; } \\
\text { Bender Jørgensen and } \\
\text { Rast-Eicher 2016) }\end{array}$ & $\begin{array}{l}\text { EXPERIMENTAL } \\
\text { RECONSTRUCTION }\end{array}$ \\
\hline $\begin{array}{l}\text { Patterns of textile } \\
\text { borders (possibly } \\
\text { starting borders) } \\
\text { Stripes, diagonal } \\
\text { stripes, zigzags } \\
\text { and dots, zigzags } \\
\text { and stripes, } \\
\text { all outlined using } \\
\text { solid lines; crocus } \\
\text { blossoms }\end{array}$ & $\begin{array}{l}\text { Adorants, } \\
\text { Saffron } \\
\text { Gatherers, } \\
\text { Mistress of } \\
\text { the Animals }\end{array}$ & $\begin{array}{l}\text { for geometric } \\
\text { patterns: } \\
\text { - warp-floating } \\
\text { (pick-up) } \\
\text { - supplemental weft } \\
\text { - weft-faced weave } \\
\text { for floral pattern: } \\
\text { - double faced } \\
\text { weave }\end{array}$ & $\begin{array}{l}\text { - rigid heddle } \\
\text { - weaving tablets } \\
\text { - off-loom } \\
\text { heddling device }\end{array}$ & no & $\begin{array}{l}\text { general appearance } \\
\text { - no analogies } \\
\text { there are analogies for: } \\
\text { - starting borders } \\
\text { - patterned borders } \\
\text { - tablet-woven } \\
\text { borders }\end{array}$ & $\begin{array}{l}\text { - crocus blossom in } \\
\text { tablet weaving: double } \\
\text { faced weave and } \\
\text { broché (silk) } \\
\text { (Spantidaki 2008) } \\
\text { - stripes in warped-faced } \\
\text { weave (no information } \\
\text { about the loom) } \\
\text { (Jones 2015) } \\
\text { - stripes, zigzags, zigzags } \\
\text { and stripes, zigzags } \\
\text { and dots in weft-faced } \\
\text { weave (in linen and } \\
\text { wool, no information } \\
\text { about the loom) } \\
\text { (Hoskins } 2015 \text { a) } \\
\text { - zigzags, zigzags and } \\
\text { stripes, and dots in } \\
\text { a warp-floating (pick-up) } \\
\text { technique on a rigid } \\
\text { heddle (wool, linen) } \\
\text { - zigzags on tablets (wool) }\end{array}$ \\
\hline $\begin{array}{l}\text { Patterns on wide } \\
\text { bands forming } \\
\text { the skirts } \\
\text { Continuous patterns } \\
\text { of forked crisscross- } \\
\text { es outlined using } \\
\text { solid lines with } \\
\text { fillers of stripes }\end{array}$ & $\begin{array}{l}\text { Adorants, } \\
\text { Saffron } \\
\text { Gatherers, } \\
\text { Mistress of } \\
\text { the Animals }\end{array}$ & $\begin{array}{l}\text { - warp or } \\
\text { weft-floating } \\
\quad \text { (pick-up) } \\
\text { - weft-faced weave } \\
\text { - supplemental } \\
\text { weft }\end{array}$ & $\begin{array}{l}\text { - rigid heddle } \\
\text { - weaving tablets } \\
\text { - warp-weighted } \\
\text { loom }\end{array}$ & no & $\begin{array}{l}\text { general appearance } \\
\text { - no analogies } \\
\text { there are analogies for: } \\
\text { - supplemental weft } \\
\text { - warp-patterned } \\
\text { textiles }\end{array}$ & $\begin{array}{l}\text { - samples in weft-faced } \\
\text { weave (in linen and } \\
\text { wool, no information } \\
\text { about the loom) } \\
\text { (Hoskins 2015a) } \\
\text { - band woven on a rigid } \\
\text { heddle (wool) }\end{array}$ \\
\hline $\begin{array}{l}\text { Pattern of a long } \\
\text { waist band } \\
\text { Continuous yo-yo } \\
\text { pattern outlined } \\
\text { using solid lines }\end{array}$ & $\begin{array}{l}\text { Wounded } \\
\text { Adorant }\end{array}$ & $\begin{array}{l}\text { - pattern created } \\
\text { using multi- } \\
\text {-coloured warp } \\
\text { - supplemental weft } \\
\text { - weft-faced weave }\end{array}$ & $\begin{array}{l}\text { - rigid heddle } \\
\text { - weaving tablets } \\
\text { - off-loom } \\
\text { heddling device }\end{array}$ & no & no & $\begin{array}{l}\text { - samples in weft-faced } \\
\text { weave (in linen and } \\
\text { wool, no information } \\
\text { about the loom) } \\
\text { (Hoskins 2015a) } \\
\text { - band woven on a rigid } \\
\text { heddle (wool) }\end{array}$ \\
\hline $\begin{array}{l}\text { Pattern of } \\
\text { a textile offering } \\
\text { Stripes and wavy } \\
\text { lines outlined by } \\
\text { various colours }\end{array}$ & $\begin{array}{l}\text { Naked boy } \\
\text { carrying } \\
\text { a garment } \\
\text { or fabric }\end{array}$ & $\begin{array}{l}\text { for wavy lines: } \\
\text { - tapestry } \\
\text { - supplemental } \\
\text { weft } \\
\text { - pattern created } \\
\text { using various } \\
\text { colours in warp } \\
\text { for stripes: } \\
\text { - patterns created } \\
\text { using various } \\
\text { colours in warp } \\
\text { or weft }\end{array}$ & $\begin{array}{l}\text { - warp-weighted } \\
\text { loom } \\
\text { - two-beam loom } \\
\text { - rigid heddle }\end{array}$ & no & $\begin{array}{l}\text { general appearance } \\
\text { - stripes created } \\
\text { using various } \\
\text { colours in warp } \\
\text { or weft }\end{array}$ & no \\
\hline $\begin{array}{l}\text { Patterns of di- } \\
\text { aphanous fabrics } \\
\text { All-over patterns } \\
\text { of polka dots, } \\
\text { lozenges outlined } \\
\text { using dotted lines, } \\
\text { crocus blossoms }\end{array}$ & Adorants & $\begin{array}{l}\text { for transparency: } \\
\text { - moisturising linen } \\
\text { fabrics with oil } \\
\text { - gauze weave } \\
\text { for patterning: } \\
\text { - woven } \\
\text { in patterns } \\
\text { in unidentified } \\
\text { technique } \\
\text { - embroidery } \\
\text { - bead work } \\
\text { - painting }\end{array}$ & $\begin{array}{l}\text { for gauze weaves: } \\
\text { - horizontal } \\
\text { ground loom } \\
\text { - warp-weighted } \\
\text { loom }\end{array}$ & no & $\begin{array}{l}\text { general appearance: } \\
\text { - no analogies } \\
\text { there are analogies for: } \\
\text { - fine linen fabrics } \\
\text { - plain gauze } \\
\text { weaves } \\
\text { - beadwork }\end{array}$ & $\begin{array}{l}\text { general appearance: } \\
\text { - two industrial fabrics } \\
\text { decorated with sewn } \\
\text { beads of carnelian or } \\
\text { glass (Jones 2013) } \\
\text { weaving technique: } \\
\text { - gauze-weaves on } \\
\text { a frame loom (wool) } \\
\text { (Mokkad 2015) } \\
\text { - gauze-weaves on } \\
\text { a warp-weighted loom } \\
\text { using cuboid weights } \\
\text { (flax, wool) }\end{array}$ \\
\hline
\end{tabular}




\begin{tabular}{|c|c|c|c|c|c|c|}
\hline $\begin{array}{l}\text { Patterns } \\
\text { on blouses or } \\
\text { chemises } \\
\text { All-over patters of } \\
\text { various lozenges } \\
\text { outlined using dot- } \\
\text { ted and solid lines } \\
\text { with a variation } \\
\text { of fillers: circles, } \\
\text { crosses and in- } \\
\text { curved diamonds }\end{array}$ & $\begin{array}{l}\text { Adorants, } \\
\text { Saffron } \\
\text { Gatherers, } \\
\text { Mistress of } \\
\text { the Animals }\end{array}$ & $\begin{array}{l}\text { for lozenges: } \\
\text { - twill weaves } \\
\text { - supplemental } \\
\text { weft } \\
\text { - warp-floating } \\
\text { (pick-up) } \\
\text { - weft-faced weave }\end{array}$ & $\begin{array}{l}\text { - warp-weighted } \\
\text { loom } \\
\text { - rigid heddle }\end{array}$ & no & $\begin{array}{l}\text { general appearance } \\
\text { - lozenges in twill } \\
\text { weaves } \\
\text { there are analogies for: } \\
\text { - supplemental weft } \\
\text { - warp-patterned } \\
\text { textiles }\end{array}$ & $\begin{array}{l}\text { - twill on a warp-weighted } \\
\text { loom (linen) } \\
\text { (Spantidaki 2018) } \\
\text { - supplemental weft on } \\
\text { a warp-weighted loom } \\
\text { (linen) } \\
\text { (Spantidaki 2018) } \\
\text { - samples in weft-faced } \\
\text { weave (in linen and } \\
\text { wool, no information } \\
\text { about the loom) } \\
\text { (Hoskins 2015a) } \\
\text {-3/1 twill on a frame } \\
\text { loom (wool) } \\
\text { - 2/2 twill on a warp } \\
\text { weighed loom (wool, } \\
\text { linen) } \\
\text { - warp-floating (pick-up) } \\
\text { on a rigid heddle } \\
\text { (wool) }\end{array}$ \\
\hline $\begin{array}{l}\begin{array}{l}\text { Patterns } \\
\text { on blouses or } \\
\text { chemises }\end{array} \\
\text { All-over patterns } \\
\text { of crocus blos- } \\
\text { soms, of lilies. } \\
\text { Patterns outlined } \\
\text { using colours }\end{array}$ & $\begin{array}{l}\text { Mistress of } \\
\text { the Animals, } \\
\text { Procession } \\
\text { of Mature } \\
\text { Women }\end{array}$ & $\begin{array}{l}\text { - tapestry } \\
\text { - compound weave } \\
\text { - double weave } \\
\text { - embroidery } \\
\text { - painting }\end{array}$ & $\begin{array}{l}\text { - warp-weighted } \\
\text { loom } \\
\text { - two-beam loom }\end{array}$ & no & $\begin{array}{l}\text { general appearance } \\
\text { - rosettes on } \\
\text { Tutankhamun } \\
\text { tunic } \\
\text { there are analogies for: } \\
\text { - tapestry }\end{array}$ & no \\
\hline $\begin{array}{l}\text { Pictorial motifs } \\
\text { on a skirt } \\
\text { Swallows in a } \\
\text { rocky landscape. } \\
\text { Motifs outlined } \\
\text { using colours }\end{array}$ & $\begin{array}{l}\text { Procession } \\
\text { of Mature } \\
\text { Women }\end{array}$ & $\begin{array}{l}\text { - tapestry } \\
\text { - embroidery } \\
\text { - painting }\end{array}$ & $\begin{array}{l}\text { - warp-weighted } \\
\text { loom } \\
\text { - two-beam loom }\end{array}$ & no & $\begin{array}{l}\text { general appearance } \\
\text { - no analogies } \\
\text { there are analogies for: } \\
\text { - tapestry }\end{array}$ & no \\
\hline
\end{tabular}

Table 1. Textile techniques suggested as plausible options for the making of patterned textiles as depicted in the wall paintings at Xeste 3, Akrotiri.

\section{Archaeological textiles from Akrotiri}

Due to unfavourable preservation conditions, archaeological textiles from Bronze Age Greece are unique finds. According to Y. Spantidatki and Ch. Moulherat, Bronze Age textiles from Greece are predominantly made of flax. They are characterised by $\mathrm{S} 2 \mathrm{z}$ plied-yarns and a balanced tabby weave (i.e. there is a similar number of threads in the warp and weft), and an average density of 15-20 threads per $\mathrm{cm}$ in both warp and weft systems. ${ }^{55}$ Yet, the limited number of preserved archaeological textiles may not represent the full diversity of fabrics which were produced in the Bronze Age.

Indeed, more technical diversity may be found in the collection of carbonised textiles discovered at Akrotiri, Thera. ${ }^{56}$ Especially fragments of one fabric, recovered in a ceremonial context together with caprine horns and a gold figurine of a goat, may be seen as a unique technical comparandum to the iconography of the textiles from Xeste $3 .^{57}$ This linen fabric, preserved in 25 small fragments, was woven in a tabby weave, with 20-22 threads per cm. S-plied threads were of a diameter ranging from 0.25 to $0.4 \mathrm{~mm}$, whereas slightly thicker threads $(0.55 \mathrm{~mm}$ in diameter $)$ were used for decoration. Several decorative techniques have been recognised, such as a decorative stitch made with

\footnotetext{
${ }^{55}$ Spantidaki and Moulherat 2012, 197.

${ }^{56}$ Spantidaki and Moulherat 2012, 187-189.

${ }^{57}$ Moulhérat and Spantidaki 2007; Spantidaki and Moulherat 2012, 187-188.
}

a thicker thread, embroidery or interwoven decoration with knots, and elaborate fringes with knots creating a tassel. ${ }^{58}$ According to Spantidaki and Moulherat, these tiny textile fragments additionally confirm the veracity of the depictions of textiles in the wall paintings from Akrotiri. ${ }^{59}$

\section{Scale of textile production at Akrotiri and textile tools found at the site}

The site of Akrotiri yielded evidence of intensive textile production. Location of large-scale weaving activity has been recognised on the basis of large concentrations of discoid loom weights. ${ }^{60}$ However, textile production has only been attested in four of 35 houses located (and only 11 fully excavated), such as the Sector A, West House (Room 3, upper floor), the north building in Complex $\Delta$ and nearly the entirety of Complex B, specifically. ${ }^{61}$ According to I. Tzachili, this restricted distribution of loom weights may suggest specialisation of textile production, yet it may also suggest that other types of looms, such as a two-beam loom may have been used in the houses without loom weights. ${ }^{62}$

\footnotetext{
${ }^{58} \mathrm{On}$ a detailed technical description of this fabric see Moulhérat and Spantidaki 2007; Spantidaki and Moulherat 2012, 187-188.

${ }^{59}$ Moulhérat and Spantidaki 2007, 51; Spantidaki and Moulherat 2012, 188.

${ }^{60}$ Cf. Tzachili 1990; Tzachili 1997; Tzachili 2007; Tzachili et al. 2015 .

${ }^{61}$ Tzachili 2007, 191; Tzachili et al. 2015.

${ }^{62}$ Tzachili 1990; Tzachili 2007.
} 


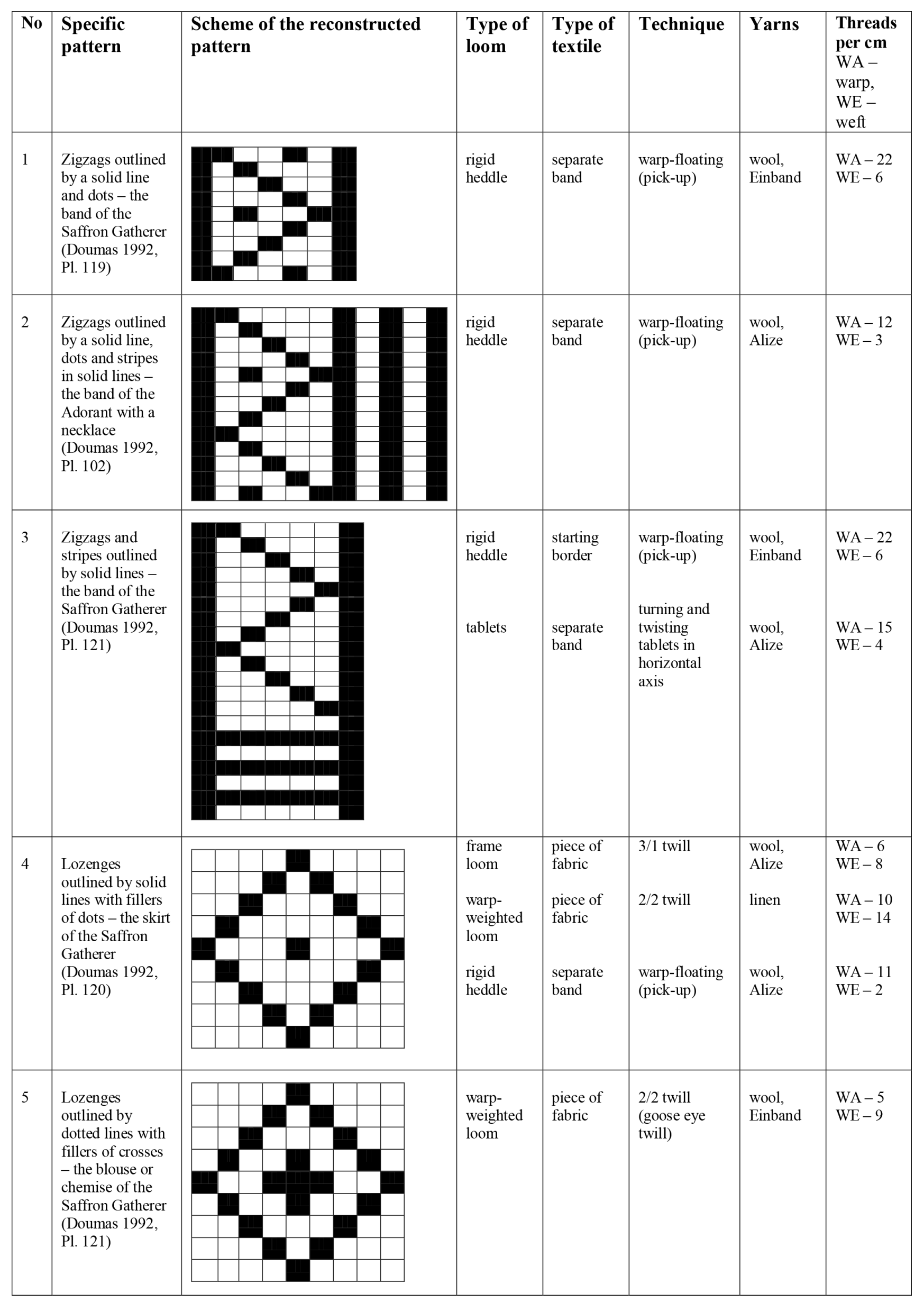

Table 2. Basic characteristics of the woven reconstructions of textile patterns discussed in the paper. 
Administrative practices related to textile production have been attested in the houses with loom weights. Lead balance weights frequently found in these houses have been connected with wool weighing. ${ }^{63}$ Inscriptions in Linear A script recording large quantities of textiles and sheep were found in Complex $\Delta .{ }^{64}$ The practice of local recording significant quantities of cloths and raw materials additionally suggests that production exceeded the needs of a single household. ${ }^{65}$

Functional parameters of the discoid loom weights from Akrotiri, i.e. their weight and thickness, suggest that tools of similar functionality were used in all the houses with loom weights. ${ }^{66}$ According to the Centre for Textile Research (CTR) experiments in spinning and weaving, functional parameters of textile tools imply parameters of yarns and textiles that were produced using them. ${ }^{67}$ On the basis of the CTR method of estimating the parameters of textiles, it has been suggested that the loom weights from Complex B would be suitable for weaving thin yarns that required tension between 10-15 g per thread, resulting in textiles characterised by $8-14$ warp threads per $\mathrm{cm} .{ }^{68}$ These calculations correspond to the density of the archaeological textiles from Akrotiri and the assumed quality of the textiles on the frescoes. ${ }^{69}$ The observed correlation may further be confirmed by a weaving experiment performed by $\mathrm{C}$. Cheval. She produced an open tabby with 20 threads per $\mathrm{cm}$ in both systems, using copies of the discoid loom weights from Akrotiri and linen threads of $0.4 \mathrm{~mm}$ in diameter. ${ }^{70}$

\section{"Weavable" textile patterns from Xeste 3}

As has been discussed above, several textile techniques have been proposed as appropriate to weave the patterns that were depicted on frescoes. Moreover, experimental reconstructions suggest that one specific pattern may have been produced using various techniques (cf. Table 1 and 2). This variety of technical choices has been investigated in my own weaving experiments undertaken to examine whether more detailed technical knowledge of Bronze Age textiles may be revealed based on the iconography of textiles.

For experimenting, I chose patterns that have generally been described by E. Barber as "easily weavable" and technically consistent. Thus, the term "weavable" is used with regards to those textile patterns that look similar to modern pattern rapports or schemes. ${ }^{71}$ These easy-to-weave patterns comprise simple geometric patterns of borders of blouses or

\footnotetext{
${ }^{63}$ Michailidou 1990, 416; Cutler 2016, 176.

${ }^{64}$ Cf. Boulotis 1998; Karnava 2008.

${ }^{65}$ Cutler 2016, 176.

${ }^{66}$ Tzachili 2007, 191.

${ }^{67}$ Andersson Strand and Nosch 2015.

${ }^{68}$ Tzachili et al. 2015.

${ }^{69}$ Cf. Moulhérat and Spantidaki 2007.

${ }^{70}$ Cheval 2008. The thread count is calculated by the author according to Cheval 2008, 24, Fig. 10.

${ }^{71}$ Ulanowska 2018a, 251-253.
}

chemises, e.g. horizontal and diagonal stripes, zigzags, zigzags with dots and zigzags with stripes, and all-over patterns of various lozenges with fillers (cf. Table 2). Such patterns could have been easily produced using implements and tools that were known at Late Bronze Age Akrotiri, e.g. the warp-weighted loom and discoid loom weights or looms for band weaving. ${ }^{72}$

\section{The author's woven reconstructions of textile patterns based on iconography - aims and methodology}

In the experiments described below, I intended to compare the following features of the woven and painted patterns: ${ }^{.3}$

- Scale of a pattern;

- Visual effect of solid or dotted lines;

- Visual elements of the pattern that may have reflected a specific weaving technique or structure of a textile.

Through this comparison, I aimed to examine whether and to what extent the painted patterns may have rendered technical features of fabrics, i.e. such features that may potentially suggest a specific weave or a specific technique of patterning. Additionally, I was concerned to what extent the wall painters may have been aware of the structure of fabrics and whether rendering a specific structure may have been important to them.

I also observed cognitive aspects of pattern weaving, such as the techniques of designing a pattern. Whenever it was possible, I designed patterns without drawing their schemes or rapports. Usually, after setting-up the warp, I built-in the pattern in a freehand controlling the symmetry and rhythmical repetitiveness of the pattern units. However, given the level of my weaving skills, ${ }^{74}$ it was not possible to use this approach in order to weave more complex weaves, e.g. lozenges in $3 / 1$ or $2 / 2$ twill. In order to heddle the warp threads properly for these complex weaves, and to control the rhythm of shed-changing in $2 / 2$ twill, I had to use modern tools, such as drawings of pattern rapports and coloured schemes illustrating the distribution of consecutive warp layers (Figs. 1 and 4).

\footnotetext{
${ }^{72}$ For the possible use of looms for band weaving in Bronze Age Greece see Ulanowska 2018b.

${ }^{73}$ The experiments were undertaken within my FUGA internship grant at the Centre for Research on Ancient Technologies of the Institute of Archaeology and Ethnology, in 2015-2017. Reconstructions of twill weaves were undertaken together with employees of the Biskupin Archaeological Museum. I would like to express my special thanks to Anna Grossman and Małgorzata Starak-Juchniewicz for their enthusiastic collaboration, as well as to Wiesław Zajączkowki, the Director of the Museum for his welcoming me there at any time. I also thank all the staff of the Biskupin Archaeological Museum for their support and creativity in solving several technical problems.

${ }^{74} \mathrm{My}$ weaving experience started in 2011 and, to a large extent, I am a self-taught weaver.
} 


\begin{tabular}{|c|l|l|l|l|l|l|l|l|l|}
\hline $\begin{array}{c}\text { Warp } \\
\text { no. }\end{array}$ & Shed 1 & Shed 2 & Shed 3 & Shed 4 & Picks & Shed 1 & Shed 2 & Shed 3 & Shed 4 \\
\hline 1 & & & & & Shed 3+4 & & & & \\
\hline 2 & & & & & Shed 2+3 & & & & \\
\hline 3 & & & & & Shed 1+2 & & & & \\
\hline 4 & & & & & Shed 1+4 & & & & \\
\hline 5 & & & & & Shed 3+4 & & & & \\
\hline 6 & & & & & Shed 1+4 & & & & \\
\hline 7 & & & & & Shed 1+2 & & & & \\
\hline 8 & & & & & Shed 2+3 & & & & \\
\hline 9 & & & & & Shed 3+4 & & & & \\
\hline 10 & & & & & Shed 2+3 & & & & \\
\hline 11 & & & & & Shed 1+2 & & & & \\
\hline 12 & & & & & Shed 1+4 & & & & \\
\hline 13 & & & & & Shed 3+4 & & & & \\
\hline 14 & & & & & Shed 1+4 & & & & \\
\hline 15 & & & & & Shed 1+2 & & & & \\
\hline 16 & & & & & Shed 2+3 & & & & \\
\hline 17 & & & & & Shed 3+4 & & & & \\
\hline
\end{tabular}

Fig. 1. Modern scheme illustrating the distribution of warp threads for $2 / 2$ lozenge twill. Designed by the author.

Considering the limited corpus of archaeological textiles I did not attempt to reproduce fabrics of parameters similar to the actual textile remains from Greece. Sometimes, the fabrics were not even intended to be the exact copies of the fabrics depicted on the frescoes. For example, I produced a yo-yo pattern that was inspired by the long waist band of one of the Adorants, ${ }^{75}$ and a forked crisscross pattern without fillers from the skirt of another Adorant ${ }^{76}$ in order to examine the general appearance of such patterns when woven using a rigid heddle (cf. Table 1). However some of the fabrics, such as the linen fabric in black and blue lozenges woven in $2 / 2$ twill, have a thread count of 24 threads per $\mathrm{cm}$ which is comparable to the thread count of archaeological textiles from Akrotiri. Basic parameters of the fabrics discussed in this paper are presented in Table 2.

In weaving experiments, I used exclusively mechanically-spun yarn: $3 \mathrm{~S} 3 \mathrm{~s} 2 \mathrm{z}$ coloured $100 \%$ woollen threads of a diameter of $2 \mathrm{~mm}$ and single z-spun $100 \%$ woollen threads of a diameter of $1 \mathrm{~mm},{ }^{77}$ and $3 \mathrm{~S}$-plied $100 \%$ linen threads of a diameter of $0.5 \mathrm{~mm} .{ }^{78}$ Fabrics were woven using rigid heddles, tablets and the warp-weighted looms with warps tensioned by copies of the discoid loom weights, and also the Cretan cuboid loom weights (cubes of the height: $4.2 \mathrm{~cm}$, width: 4.2. cm, weight: $130 \mathrm{~g}$ ). ${ }^{79}$ Though the latter were not known from Akrotiri, these small cuboid weights, with their

${ }^{75}$ Doumas 1992, Pl. 105.

${ }^{76}$ Doumas 1992, Pl. 107.

${ }^{77}$ Commercial names: Alize Cashmira fine and Einband, respectively.

${ }^{78}$ Commercial names: $660-00 x x-x$ for various colours $56 \times 3$ ŽLD TEX.

${ }^{79}$ The copies of these tools were modeled by students thanks to the courtesy of Dr Joanne Cutler who shared with us her data about cuboid weights from Crete. large thickness, proved to be very expedient tools for twill weaving in our experimenting, and therefore they were chosen to weave the pattern of blue lozenges with dot filler in 2/2 twill (Table 2, pattern no. 4, Fig. 5:b).

\section{Patterns of textile borders}

Geometric patterns shown on the cloths' borders were woven using simple heddling devices, such a rigid heddle, and weaving tablets (Table 2, nos 1-3). Although none of these implements has been attested by archaeological evidence from Bronze Age Greece, knowledge of some kind of band looms was indeed possible, if not a prerequisite in the warp-weighted loom technology. ${ }^{80}$ All bands are warp-faced (i.e. weft threads are barely visible), and the patterns were created using the warp threads exclusively.

Scale of patterns: the width of the woven borders, ranging between 2-3 cm, depended on the structure of pattern, i.e. the minimal number of warp threads required to weave a pattern repeat and diameter of threads. The width of the band would be narrower if finer threads were used. Comparing the width of the painted borders with the general proportions of female figures, the size of the woven bands seems to fit a scale suggested by the paintings. In other words, the scale of the painted patterns corresponds to the structure of woven patterns and actual size of bands.

Visual effect of solid or dotted lines: all patterns belonging to this category were rendered using solid lines in the paintings. This visual effect is characteristic for bands woven on tablets, whereas patterns woven on a rigid heddle create a visual effect of dotted lines (Fig. 2:a).

\footnotetext{
${ }^{80}$ For a discussion about possible use of band looms in Bronze Age Greece see Ulanowska 2018 b.
} 

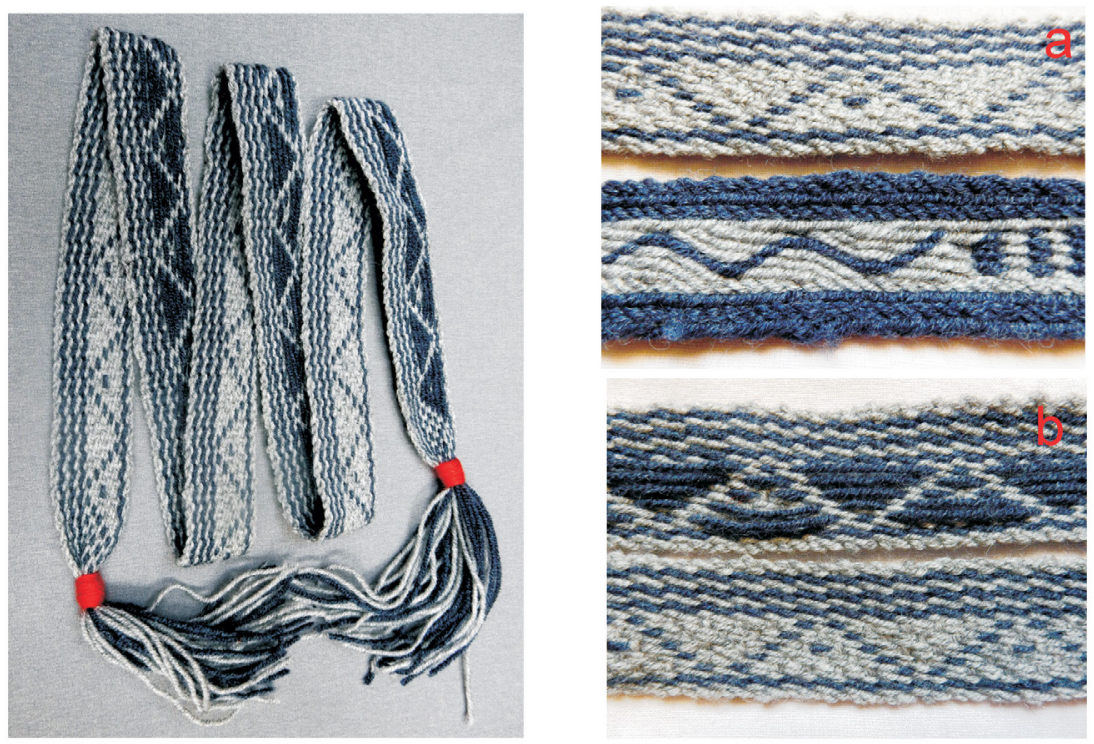

Fig. 2. Band woven on a rigid heddle in a warp-floating (pick-up) technique. a - a comparison between the visual effect of the pattern outlined in dotted lines (warp-floating technique) and solid lines (tablet weaving); $b$ - dots between zigzags in the warp-floating technique. Photo A. Ulanowska.

Visual elements of the pattern that may have reflected a specific weaving technique or specific structure of a textile: the bands that were woven on rigid heddles in warp-floating (warp-pick up) technique are characterised by warp-floats at one side (Fig. 2:b). Since long floating threads make the structure of a fabric less consistent, creating inter-woven dots (nos 1,2) or horizontal stripes (no. 3) such as depicted on frescoes, would help to keep the entire fabric more solid (Figs. 2; 2:b).

Patterns woven as a starting border: only the pattern no. 3 was woven as a starting border. The starting border creates the upper border of a larger fabric to be produced on the warp-weighted loom. Usually, it is made using a band loom, e.g. a rigid heddle or tablets. The length of the starting border determines the width of the final fabric. Its weft threads create long loops at one side of the band. In the next operational step, these loops are used as the warp threads of a textile woven on a warp-weighted loom (Fig. 3). Preserved starting borders from the Bronze Age in central Europe were woven in a repp tabby, plaited or twined, possibly on tablets. ${ }^{81}$

In order to make the starting border in pattern no. 3 , the structure of the final fabric (no. 5 - lozenges outlined by dotted lines with fillers of crosses) had to be analysed. The reddish colour of the ground and a dark-brown colour of dotted lines forming the lozenges on the blouse or chemise of the young Saffron Gatherer (no. 5) imply that weaving a similar fabric would require using reddish warp threads. Thus, reddish

\footnotetext{
${ }^{81}$ Grömer et al. 2013
}

threads were chosen for the weft of the starting border (Fig. 3). The border was woven on a rigid heddle in warp-floating (pick-up) technique. In this technique the black warp threads creating the pattern are picked-up or left floating, according to the design. When the warp is floating, the reddish threads are visible between blue warp threads of the border (Fig. 3). There is no analogy to this visual effect on the fresco.

\section{All-over patterns of various lozenges}

These patterns were shown on several fabrics on frescoes in Xeste 3, including representations of diaphanous textiles (cf. Tables 1 and 2). The lozenges with dot and cross fillers were reconstructed in 3/1 twill (patterns nos 4-5) woven on a frame loom with heddles, in $2 / 2$ twill woven on the warp-weighted loom, as well as in a tabby woven on the rigid heddle using the warp-floating (pick-up) technique (no. 4). There is no archaeological evidence suggesting the use of a frame loom in Bronze Age Greece. Yet, I decided to use this simple tool in order to understand better how to divide the layers of warp threads for twill weaving (Fig. 4).

Scale of patterns: the size of lozenges depended on the diameter of the threads and the structure of the pattern, however the type of filler may not influence the size of a lozenge (cf. Table 2). In woven samples, the size of the lozenges ranges from $1 \times 0.8 \mathrm{~cm}$ (no. 4, 2/2 twill, dot filler), $1.7 \times 1.7 \mathrm{~cm}$ (no. $4,1 / 3$ twill, dot filler), $2 \times 1.2 \mathrm{~cm}$ (no. 5, 2/2 twill, cross filler) to $2.8 \times 2 \mathrm{~cm}$ (no 4, tabby, dot filler) (Fig. 5).

Comparing the scale of the painted lozenges with the general proportions of female figures, the painted lozenges seem to be larger than woven lozenges, regardless the weaving 

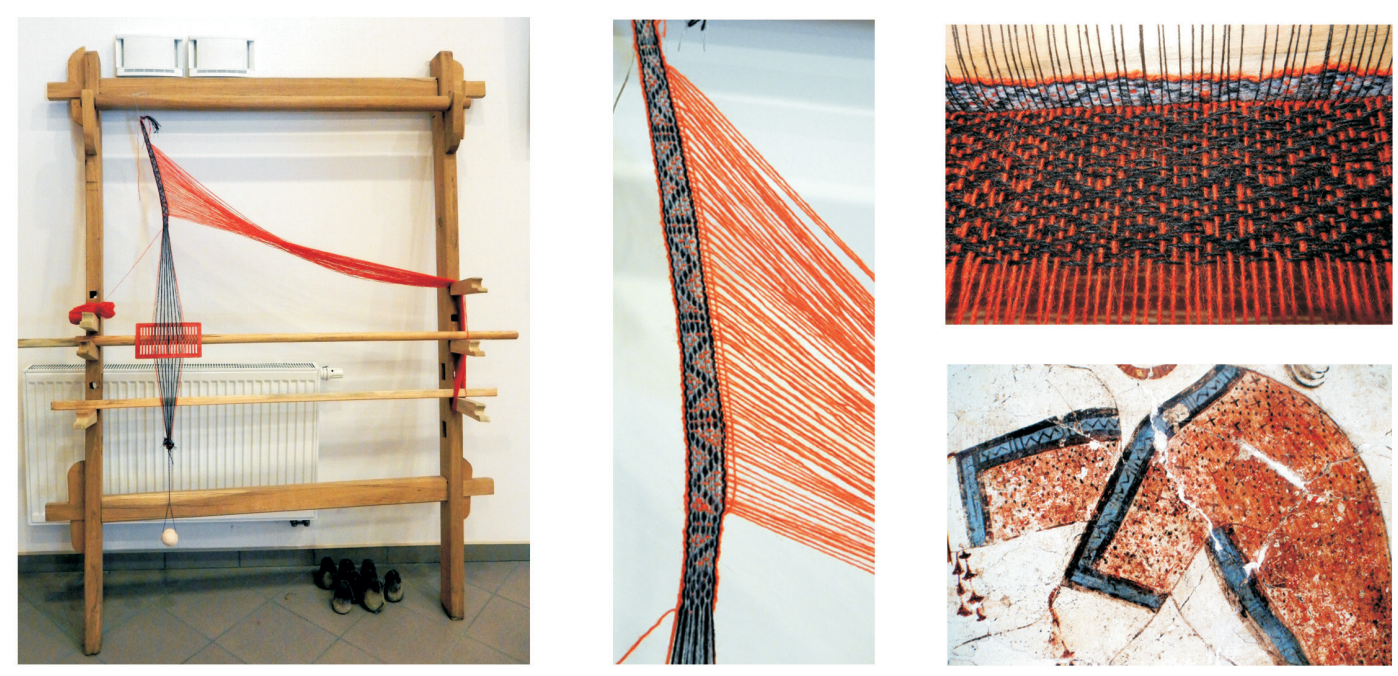

Fig. 3.Weaving a starting border in a pattern of zigzags and stripes for a fabric of lozenges with fillers of crosses (patterns no 3 and 5 in Table 2). Patterns inspired by the costume of the young Saffron Gatherer from Room 3a, East wall (fragment of the wall painting after Doumas 1992, Pls. 120-121, Photo A. Ulanowska).

technique, type of filler and diameter of threads. This apparent difference may suggest that either the weaving techniques were not chosen properly or, that the scale of the pattern is exaggerated on the frescoes to make the details of the pattern more clearly recognisable.

Visual effect of solid or dotted lines: the painted lozenges were rendered using solid lines, as well as the dotted lines. None of the woven lozenges has the visual effect of a solid line, yet the lozenges woven in $2 / 2$ twill look more solid in comparison to the lozenges woven in 3/1 twill and tabby (Fig. 5). The latter look like they are outlined by dotted lines and they resemble the appearance of the dotted lozenges on the frescoes.

Visual elements of the pattern that may have reflected a specific weaving technique or specific structure of a textile: on the frescoes, the number of painted dots that create a single lozenge varies in one depiction. One side of a lozenge without a filler could have been outlined by four to five dots (diaphanous fabric of the Adorant with the necklace). Four to six dots (blouse or chemise of the Saffron Gatherer, no. 5) and five to six dots (skirt of the Adorant with the necklace) were painted to render the lozenges with a cross filler and incurved diamond filler accordingly. The 'five-dots' lozenges correspond visually to the modern pattern schemes and a technical observation that five weft picks are required to weave half of a lozenge with a dot or a cross filler. Therefore, five dots at each side of the painted lozenge may refer to the actual structure of the lozenge woven with a dot and cross filler (cf. Table 2; Fig. 5). Six dots at each side of a painted lozenge should thus correspond to the pattern scheme of a six-pick lozenge with a cross filler (not illustrated), since six weft picks are required to weave half of such a lozenge, whereas the 'four-dots' lozenge would correspond to four weft picks required to weave half of a lozenge without a filler, or with a dot filler (cf. Fig. 5:d).

\section{Conclusions}

On the whole, the Aegean iconography of patterned textiles proves to be a reliable and valuable source for studying textiles in Bronze Age Greece. However, as a potential source of knowledge of patterning techniques, the significance of the iconography appears less clear.

The iconographic analysis of the textile patterns depicted in Xeste 3, Akrotiri and patterns experimentally woven on the basis of these depictions demonstrates that simple geometric patterns could have been produced using various weaving techniques and tools. However, the panoply of textile tools available in the Bronze Age and range of textile techniques demonstrated by archaeological textiles delimits the number of possible choices. The most certain is the use of the warp-weighted loom and, possibly, the use of an unspecific type of the band loom(s) that may be speculated on the basis of the warp-weighted loom technology. Archaeological textiles demonstrate that repp tabby, supplemental weft/warp weaving, tablet weaving, twills and tapestry were already known in Bronze Age Europe and the Mediterranean ${ }^{82}$ However, since no patterned textiles or weaves other than tabby have been preserved from Bronze Age Greece, the knowledge of the above-mentioned techniques must remain conjectural even, if the Aegean weavers had at their disposal tools suitable to produce such fabrics.

${ }^{82}$ Cf. Barber 1991; Vogelsang-Eastwood 1999; James et al. 2009; Gleba and Mannering 2012; Grömer et al. 2013; Skals et al. 2015; Bender Jørgensen and Rast-Eicher 2016. 

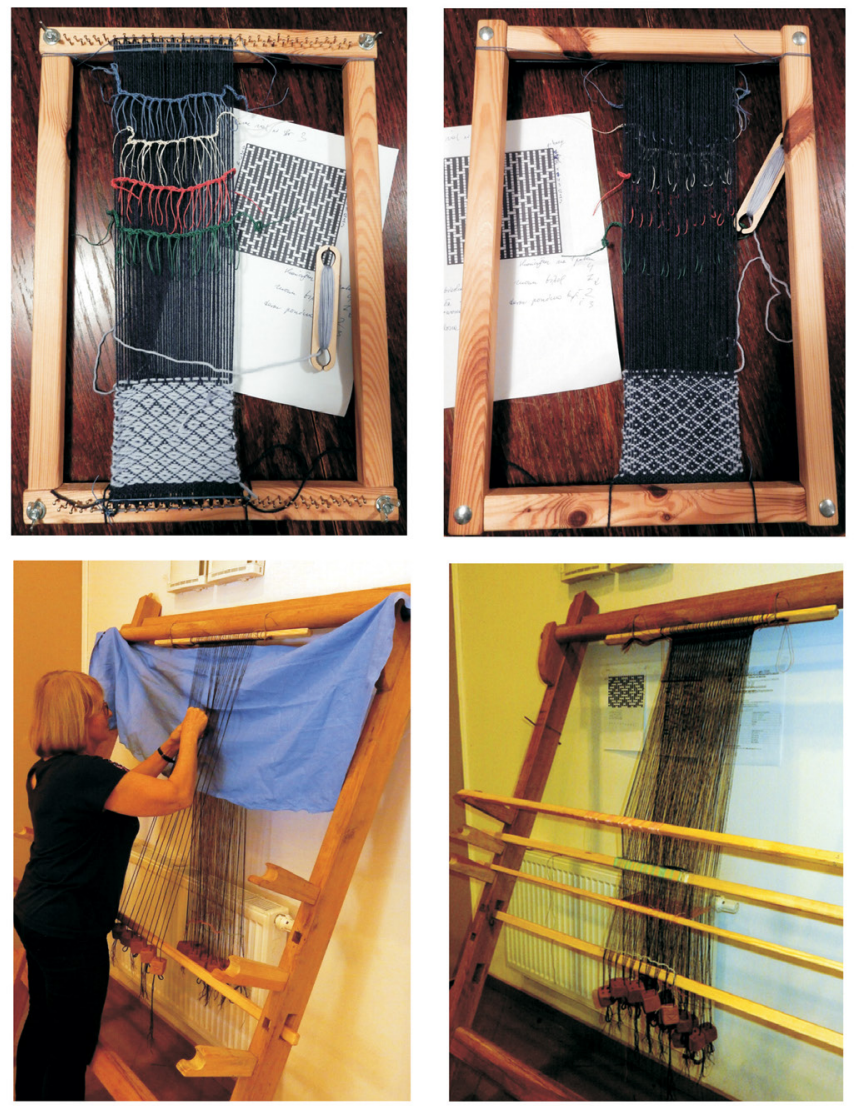

Fig. 4. Cognitive aspects of pattern weaving: a frame loom set-up for lozenges in for $1 / 3$ twill and setting-up the warp-weighted loom for weaving lozenges in $2 / 2$ twill with copies of the cuboid loom weights. In the bottom left picture Anna Grossman from the Biskupin Archaeological Museum is chaining the last layer of warp threads. Photo A. Ulanowska.
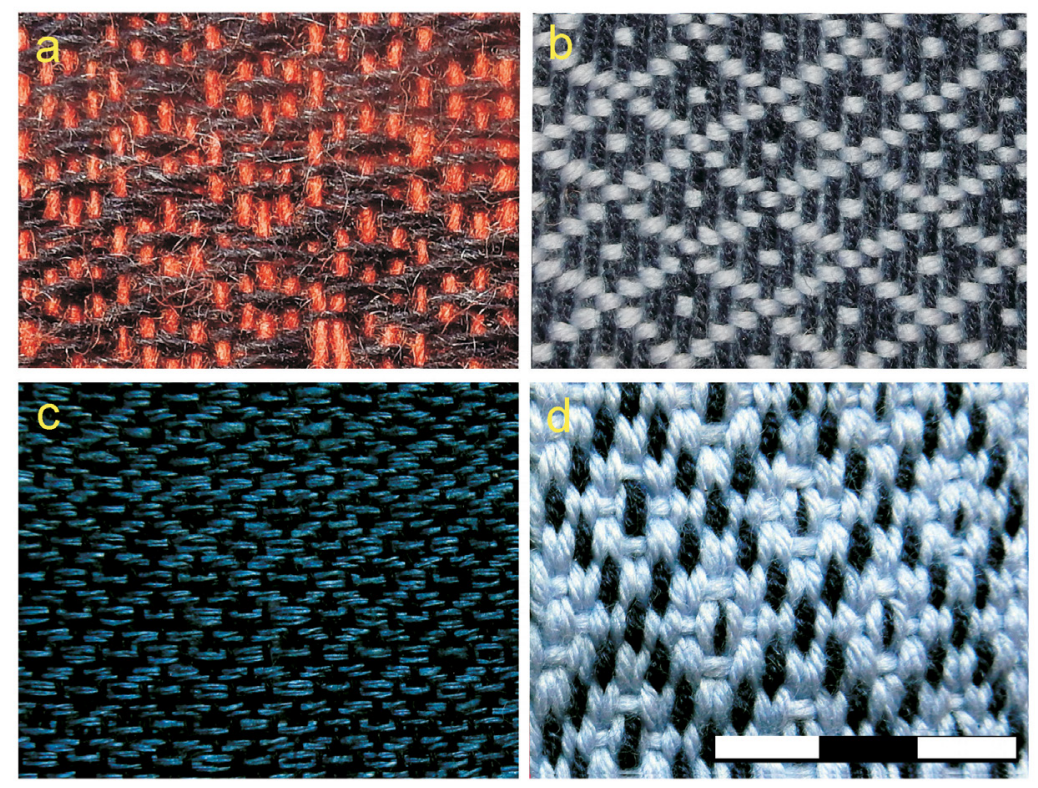

Fig. 5. General appearance and size of the woven lozenges, according to manufacturing technique and diameter of thread: $\mathrm{a}-2 / 2$ twill with a cross filler $(\mathrm{c} .2 \times 1.2 \mathrm{~cm}) ; \mathrm{b}-1 / 3$ twill with a dot filler $(\mathrm{c} .1 .7 \times 1.7 \mathrm{~cm}) ; \mathrm{c}-2 / 2$ twill with a dot filler $(\mathrm{c} .1 \times 0.8 \mathrm{~cm})$; $\mathrm{d}$ - warp-floating technique, tabby, dot filler $(\mathrm{c} .2 \times 2.8 \mathrm{~cm})$. Photo A. Ulanowska. 
Since the same patterns produced using different techniques and tools have a similar appearance, it seems that the possibility of recognising one specific technique of patterning on the basis of the iconography is rather limited, if possible at all. However, the detailed analysis of the geometric patterns that have been described as "weavable", reveals their visual similarity to modern pattern schemes or pattern rapports, suggesting that the painted patterns were indeed intended to render specific fabrics. Moreover, several details of the iconography of the "weavable" patterns may be explained in terms of weaving techniques. For example, dots in-between the zigzags may have been woven as elements that reinforce the structure of the fabric produced in the warp-floating (pick-up) technique. The dotted lines that outlined patterns of lozenges correspond well to the appearance of woven patterns in warp-floating technique and 3/1 twill. Even the number of dots painted at one side of the lozenge corresponds roughly to the number of weft picks required to weave half of a lozenge with fillers of dots or crosses accordingly. The solid lines of zigzags and lozenges, in weaving could have been achieved by tablet weaving and $2 / 2$ twills. It may be therefore, suggested that the textile patterns were painted with a special care to illustrate several features characteristic of the woven patterns.

While the patterns of the bands or textile borders, when compared to their woven reconstructions, seem to be depicted in an appropriate scale, the sizes of the lozenges with fillers seems to be exaggerated on the frescoes. By this enlargement, the structure of the pattern is more recognisable and differences between the fillers are clear. It may be suggested, therefore, that the wall painters were especially interested in rendering tiny differences between visually similar fabrics. This observation may additionally imply that the wall painters had indeed some general textile knowledge and that rendering the subtle varieties of similar patterns was an important issue to them, possibly in order to show the assortment of patterns that we might assume had been produced by the Akrotirian weavers.

However, several of the painted patterns, such as patterns on diaphanous fabrics and, especially, pictorial motifs, such as swallows in a rocky landscape on the skirt of the Lady of the Landscape do not find parallels in archaeological textiles found in the Bronze Age contexts outside Greece, e.g. in Europe or Egypt. The techniques of manufacturing these exquisite fabrics are not easy to suggest, yet they might possibly have been woven in a tapestry technique (rocky landscape) or as a combination of gauze weave with beadwork or embroidery (patterns on diaphanous fabrics). However, it is also possible that these patterns were rather the creations of the wall painters intended as depictions of 'supernatural' quality-textiles and craftsmanship that would have exceeded the technical possibilities of the Akrotirian weavers.

As has been demonstrated, the accuracy of woven patterns reconstructed on the basis of the iconography must remain hypothetical. Nevertheless, experimental recreation of patterns and textile structures inspired by art, using fibres and techniques that we consider appropriate for the time, as well as copies of the tools found at archaeological sites, provides important information about ancient technical knowledge and cognitive processes. It may be suggested, however, that experimental reconstructions of textiles based on the iconography, should rather aim at a better understanding of the conceptual processes of transforming three-dimensional textile patterns into two-dimensional media such as wall-paintings, than proving the knowledge of a specific patterning techniques in Bronze Age Greece.

\section{Bibliography}

Aloupi E., Karydas A. G., Paradellis T. 2000. Pigment Analysis of Wall Paintings and Ceramics from Greece and Cyprus. The Optimum Use of X-Ray Spectrometry on Specific Archaeological Issues. "X-Ray Spectrometry" 29, 18-24.

Andersson Strand E., Nosch M.-L. (eds.) 2015. Tools, Textiles and Contexts. Investigating Textile Production in the Aegean and Eastern Mediterranean Bronze Age. Ancient Textiles Series 21. Oxford, Philadelphia.

Barber E. J. W. 1991. Prehistoric Textiles. The Development of Cloth in the Neolithic and Bronze Ages with Special Reference to the Aegean. Princeton.

Barber E. J. W. 1994. Women's Work. The First 20,000 Years. Women, Cloth, and Society in Early Times. New York, London.

Barber E. J. W. 2003. Archaeology by Experiment and Reproduction. In: K. P. Foster, R. Laffineur (eds.), METRON. Measuring the Aegean Bronze Age. Proceedings of the $9^{\text {th }}$ International Aegean Conference, New Heaven, Yale University, 18-19 April 2002. Aegaeum 24. Liège, 193-195.

Barber E. J. W. 2016. Minoans, Mycenaeans, and Keftiu. In: M. C. Shaw, A. P. Chapin, Woven Threads. Patterned Textiles of the Aegean Bronze Age. Ancient Textiles Series 22. Oxford, Philadelphia, 205-237.

Bender Jørgensen L., Rast-Eicher A. 2016. Innovations in European Bronze Age Textiles. "Prähistorische Zeitschrift" $91(1), 68-102$.

Blakolmer F. 2012. Body Marks and Textile Ornaments in Aegean Iconography: Their Meaning and Symbolism. In: M.-L. Nosch, R. Laffineur (eds.), KOSMOS. Jewellery, Adornment and Textiles in the Aegean Bronze Age. Proceedings of the $13^{\text {th }}$ International Aegean Conference / $13^{e}$ Rencontre égéenne internationale, University of Copenhagen, Danish National Research Foundation's Centre for Textile Research, 21-26 April 2010. Aegaeum 33. Leuven, Liège, 325-333. 
Boulotis C. 1998. Les nouveaux documents en linéaire A d'Akrotiri (Théra): remarques préliminaires. "Bulletin de correspondance hellénique" 122, 407-411.

Bravermanová M., Březinová H., Malcolm-Davies J. (eds.) 2017. Archaeological Textiles - Links between Past and Present. North European Symposium for Archaeological Textiles XIII. Liberec, Praha.

Breniquet C., Michel C. (eds.) 2014. Wool Economy in the Ancient Near East and the Aegean. From the Beginnings of Sheep Husbandry to Institutional Textile Industry. Ancient Textiles Series 17. Oxford, Philadelphia.

Brysbaert A. 2007. Murex Uses in Plaster Features in the Aegean and Eastern Mediterranean Bronze Age. "Mediterranean Archaeology and Archaeometry" 7 (2), 29-51.

Brysbaert A. 2008. Painted Plaster from Bronze Age Thebes, Boeotia (Greece): A Technological Study. "Journal of Archaeological Science" 35, 2761-2769.

Brysbaert A., Melessanaki K., Anglos D. 2006. Pigment Analysis in Bronze Age Aegean and Eastern Mediterranean Painted Plaster by Laser-Induced Breakdown Spectroscopy (LIBS). "Journal of Archaeological Science” 33, 1095-1104.

Burke B. 2010. From Minos to Midas: Ancient Cloth Production in the Aegean and in Anatolia. Ancient Textiles Series 7. Oxford, Oakville.

Burke B. 2012. Looking for Sea-Silk in the Bronze Age Aegean. In: M.-L. Nosch, R. Laffineur (eds.), KOSMOS. Jewellery, Adornment and Textiles in the Aegean Bronze Age. Proceedings of the $13^{\text {th }}$ International Aegean Conference / $13^{e}$ Rencontre égéenne internationale, University of Copenhagen, Danish National Research Foundation's Centre for Textile Research, 21-26 April 2010. Aegaeum 33. Leuven, Liège, 171-177.

Burnham D. K. 1964. Warp and Weft. A Textile Terminology. Toronto, Ontario.

Carington Smith J. 1975. Spinning, Weaving and Textile Manufacture in Prehistoric Greece - from the Beginning of the Neolithic to the End of the Mycenaean Ages; With Particular Reference to the Evidence Found on Archaeological Excavations. Unpublished $\mathrm{PhD}$ thesis. University of Tasmania.

Chapin A. P. 1997-2000. Maidenhood and Marriage: The Reproductive Lives of the Girls and Women from Xeste 3, Thera. "Aegaean Archaeology" 4, 7-25.

Chapin A. P. 2007. Boys Will Be Boys: Youth and Gender Identity in the Theran Frescoes. In: A. Cohen, J. B. Rutter (eds.), Constructions of Childhood in Ancient Greece and Italy. Hesperia Supplement 41. Princeton, New Jersey, 229-255.

Chapin A. P. 2008. The Lady of the Landscape: An Investigation of Aegean Costuming and the Xeste 3 Frescoes. In: C. S. Colbourn, M. K. Heyn (eds.), Reading a Dynamic Canvas: Adornment in the Ancient Mediterranean World. Newcastle, 48-83.

Chapin A. P. 2009. Constructions of Male Youth and Gender in Aegean Art: The Evidence from Late Bronze Age Crete and Thera. In: K. Kopaka (ed.), FYLO. Engendering Prehistoric Stratigraphies in the Aegean and Mediterranean, Proceedings of an International Conference, University of Crete, Rethymno 2-5 June 2005. Aegaeum 30. Liège, $175-182$.

Chapin A. P. 2016. Spinning Ariadne's Thread: Sources and Methodologies. In: M. C. Shaw, A. P. Chapin, Woven Threads. Patterned Textiles of the Aegean Bronze Age. Ancient Textiles Series 22. Oxford, Philadelphia, 1-16.

Cheval C. 2008. Protohistoric Weaving, the Minoan Loom-Weights: A First Approach. In: C. Alfaro, L. Karali (eds.), Vestidos, Textiles y Tintes. Estudios sobre la producción de bienes de consumo en la Antigüedad. Actas del II Symposium Internacional sobre Textiles y Tintes del Mediterráneo en el mundo antiguo (Atenas, 24 al 26 de noviembre, 2005). PURPUREAE VESTES II. Textiles and Dyes in Antiquity. València, 19-24.

Cutler J. 2016. Fashioning Identity: Weaving Technology, Dress and Cultural Change in the Middle and Late Bronze Age Southern Aegean. In: E. Gorogianni, P. Pavúk, N. Girella (eds.), Beyond Thalassocracies. Understanding Processes of Minoanisation and Mycenaeanisation in the Aegean. Oxford, Philadelphia, 172-185.

Doumas Ch. 1992. The Wall Paintings from Thera. Athens.

Douskos I. 1980. The Crocuses of Santorini. In: Ch. Doumas (ed.), Thera and the Aegean World. Vol. II. London, 141-146.

Egan E. C. 2016. Textile and Stone Patterns in the Painted Floors of the Mycenaean Palaces. In: M. C. Shaw, A. P. Chapin, Woven Threads. Patterned Textiles of the Aegean Bronze Age. Ancient Textiles Series 22. Oxford, Philadelphia, 131-148.

Evans E. 1921-1935. The Palace of Minos at Knossos. Vol. I-IV. London.

Gillis C., Nosch M.-L. B. (eds.) 2007. Ancient Textiles, Production, Craft and Society. Proceedings of the First International Conference on Ancient Textiles, Held at Lund Sweden and Copenhagen, Denmark, on March 19-23, 2003. Ancient Textiles Series 1. Oxford.

Gleba M., Mannering U. (eds.) 2012. Textiles and Textile Production in Europe: From Prehistory to AD 400. Ancient Textiles Series 11. Oxford, Oakville.

Grömer K., Kern A., Reschreiter H., Rösel-Mautendorfer H. (eds.) 2013. Textiles from Hallstatt. Weaving Culture in Bronze Age and Iron Age Salt Mines / Textilien aus Hallstatt. Gewebte Kultur aus dem bronze- und eisenzeitlichen Salzbergwerk. Archaeolingua 29. Budapest. 
Hackl R. 1912. Die Fussböden. In: G. Rodenwaldt, Tiryns II. Die Fresken des Palastes. Athen, 222-237.

Harris S. 2012. From the Parochial to the Universal: Comparing Cloth Cultures in the Bronze Age. "European Journal of Archaeology" 15 (1), 61-97.

Hoskins N. A. 2015a. Fabric Patterns Found in Minoan Frescoes. "Complex Weavers Journal” 107 (February), 21-29.

Hoskins N. A. 2015b. Fabric Patterns Found in Minoan Frescoes from Crete. “Complex Weavers Journal” 108 (June), 21-24. Immerwhar S. A. 1990. Aegean Painting in the Bronze Age. University Park, London.

James M. A, Reifah N., Mukherjee A. J., Crump M. P., Gates P. J., Sandor P., Robertson F., Pfälzner P., Evershed R. P. 2009. High Prestige Royal Purple Dyed Textiles from the Bronze Age Royal Tomb at Qatna, Syria. "Antiquity” 83 (322), 1109-1118.

Jarva E., Lipkin S. 2014. Ancient Textiles Were Expensive. How Do We Know That? "Faravid" 38, 23-38.

Jones B. R. 2015. Ariadne's Threads: The Construction and Significance of Clothes in the Aegean Bronze Age. Aegaeum 38. Leuven, Liége.

Kantor H. 1947. The Aegean and the Orient in the Second Millennium B.C. "American Journal of Archaeology" 51 (1), 1-103, Pls. I-XXVI.

Karnava A. 2008. Written and Stamped Records in the Late Bronze Age Cyclades: The Sea Journeys of an Administration.

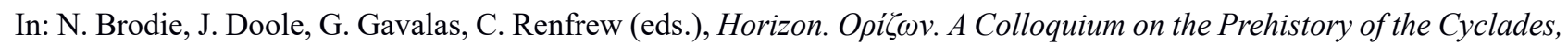
McDonald Institute Monographs. Cambridge, 377-386.

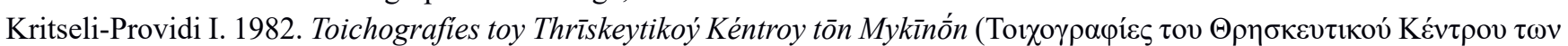
Mvкпvóv). Athenai.

Landenius Enegren H., Meo F. (eds.) 2017. Treasures from the Sea. Sea Silk and Shellfish Purple Dye in Antiquity. Ancient Textiles Series 30. Oxford, Philadelphia.

Lang M. L. 1969. The Palace of Nestor at Pylos in Western Messenia. Vol. II. The Frescoes. Princeton, London.

Lillethun A. 2003. The Recreation of Aegean Cloth and Clothing. In: K. P. Foster, R. Laffineur (eds.), METRON. Measuring the Aegean Bronze Age. Proceedings of the $9^{\text {th }}$ International Aegean Conference, New Heaven, Yale University, $18-$ 19 April 2002. Aegaeum 24. Liège, 463-472.

Lillethun A. 2012. Finding the Flounced Skirt (Back Apron). In: M.-L. Nosch, R. Laffineur (eds.), KOSMOS. Jewellery, Adornment and Textiles in the Aegean Bronze Age. Proceedings of the $13^{\text {th }}$ International Aegean Conference $/ 13^{e}$ Rencontre égéenne internationale, University of Copenhagen, Danish National Research Foundation's Centre for Textile Research, 21-26 April 2010. Aegaeum 33. Leuven, Liège, 251-254.

Marcar A. 2004. Aegean Costume and the Dating of the Knossian Frescoes. In: G. Cadogan, E. Hatzikaki, A. Vasilakis (eds.), Knossos: Palace, City, State. Proceedings of the Conference in Herakleion organised by the British School of Athens and the 23rd Ephoreia of Prehistoric and Classical Antiquities of Herakleion, in November 2000, for the Centenary of Sir Arthur Evans's Excavations at Knossos. British School at Athens Studies 12. London, 225-238.

Marinatos N. 2015. Akrotiri, Thera and the East Mediterranean. Athens.

McGillivray J. A., Driessen J. M., Sackett L. H. 2000. The Palaikastro Kouros: A Minoan Chryselephantine Statuette and its Aegean Bronze Age Context. British School at Athens 6. London.

Michailidou A. 1990. The Lead Weights from Akrotiri: The Archaeological Record. In: D. A. Hardy, C. G. Doumas, J. A. Sakellarakis, P. M. Warren (eds.), Thera and the Aegean World III. Proceedings of the Third International Congress, Santorini, Greece, 3-9 September 1989. London, 407-419.

Moulhérat C., Spantidaki Y. 2007. Preliminary Results from the Textiles Discovered in Santorini. In: A. Rast-Eicher, R. Windler (eds.), Archäologische Textilfunde. Archaeological textiles. North European Symposium for Archaeological Textiles IX. Ennenda, 49-52.

Nosch M.-L., Laffineur R. (eds.) 2012. KOSMOS. Jewellery, Adornment and Textiles in the Aegean Bronze Age. Proceedings of the $13^{\text {th }}$ International Aegean Conference / $13^{e}$ Rencontre égéenne internationale, University of Copenhagen, Danish National Research Foundation's Centre for Textile Research, 21-26 April 2010. Aegaeum 33. Leuven, Liège.

Nosch M.-L. 2015. The Loom and the Ship in Ancient Greece. Shared Knowledge, Shared Terminology, Cross-Crafts, or Cognitive Maritime-Textile Archaeology. In: H. Harich-Shwarzbauer (ed.), Weben und Gewebe in der Antike: Materialität - Repräsentation - Episteme - Metapoetik / Texts and Textiles in the Ancient World. Materiality - Representation - Episteme-Metapoetics. Oxford, Philadelphia, 109-132.

Nosch M.-L. 2016. Spinning Gold and Casting Textiles. In: J. Driessen (ed.), RA-PI-NE-U. Studies on the Mycenaean World Offered to Robert Laffineur for His $70^{\text {th }}$ Birthday. Actes de colloques. “Aegis" 10, Louvain, 221-232.

Panagiotakopulu E., Buckland P. C., Day P. M., Doumas C., Sarpaki A., Skidmore P. 1997. A Lepidopterous Cocoon from Thera and Evidence for Silk in the Aegean Bronze Age. "Antiquity" 71 (272), 420-429.

Peterson Murray S. 2016. Patterned Textiles as Costume in Aegean Art. In: M. C. Shaw, A. P. Chapin, Woven Threads. Patterned Textiles of the Aegean Bronze Age. Ancient Textiles Series 22. Oxford, Philadelphia, 43-104. 
Rahmstorf L. 2015. An Introduction to the Investigation of Archaeological Textile Tools. In: E. Andersson Strand, M.-L. Nosch (eds.), Tools, Textiles and Contexts. Investigating Textile Production in the Aegean and Eastern Mediterranean Bronze Age. Ancient Textiles Series 21. Oxford, Philadelphia, 1-24.

Rehak P. 2002. Imag(in)ing a Women's World in Prehistoric Greece: The Frescoes from Xeste 3 at Akrotiri. In: N. Rabinowitz, L. Auanger (eds.), Among Women. From the Homosocial to Homoerotic in the Ancient World. Texas, 34-59.

Sackett L. H. 2006. The Palaikastro Kouros: A Masterpiece of Minoan Sculpture in Ivory and Gold. Athens.

Shaw M. C. 2016. String Lines, the Artist's Grid, and the Representation of Textiles in Fresco. In: M. C. Shaw, A. P. Chapin, Woven Threads. Patterned Textiles of the Aegean Bronze Age. Ancient Textiles Series 22. Oxford, Philadelphia.

Shaw M. C., Chapin A. P. 2016. Woven Threads. Patterned Textiles of the Aegean Bronze Age. Ancient Textiles Series 22. Oxford, Philadelphia

Siennicka M., Rahmstorf L., Ulanowska A. 2018. Introduction. In: M. Siennicka, L. Rahmstorf, A. Ulanowska (eds.), First Textiles. The Beginnings of Textile Manufacture in Europe and the Mediterranean. Proceedings of the EAA Session Held in Istanbul (2014) and the 'First Textiles' Conference in Copenhagen (2015). Ancient Textiles Series 32. Oxford, 1-16.

Skals I., Möller-Wiering S., Nosch M.-L. 2015. Survey of Archaeological Textile Remains from the Aegean and Eastern Mediterranean Area. In: E. Andersson Strand, M.-L. Nosch (eds.), Tools, Textiles and Contexts. Investigating Textile Production in the Aegean and Eastern Mediterranean Bronze Age. Ancient Textiles Series 21. Oxford, Philadelphia, 61-74.

Spantidaki Y., Moulherat Ch. 2012. Greece. In: M. Gleba, U. Mannering (eds.), Textiles and Textile Production in Europe: From Prehistory to AD 400. Ancient Textiles Series 11. Oxford, Oakville, 185-200.

Spantidaki S. 2008. Preliminary Results of the Reconstruction of Theran Textiles. In: C. Alfaro, L. Karalis (eds.), Vestidos, Textiles y Tintes. Estudios sobre la producción de bienes de consumo en la Antigüeadad. Actas del II Symposium Internacional sobre Textiles y Tintes del Mediterráneo en el mundo antiguo (Atenas, 24 al 26 de noviembre, 2005), PURPUREAE VESTES II. Textiles and Dyes in Antiquity. València, 43-47.

Tzachili I. 1990. All Important yet Elusive: Looking for Evidence of Cloth-Making at Akrotiri. In D. A. Hardy, C. G. Doumas, J. A. Sakellarakis, P. M. Warren (eds.), Thera and the Aegean World III. Proceedings of the Third International Congress, Santorini, Greece, 3-9 September 1989. London, 380-389.

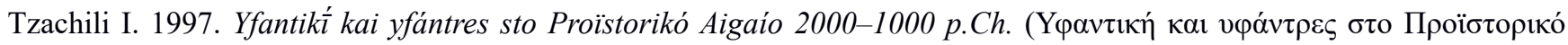

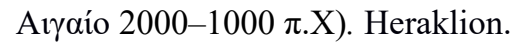

Tzachili I. 2007. Weaving at Akrotiri, Thera: Defining Cloth-Making Activities as Social Process in a Late Bronze Age Aegean Town. In: C. Gillis, M-L. B. Nosch (eds.), Ancient Textiles, Production, Craft and Society. Proceedings of the First International Conference on Ancient Textiles, Held at Lund Sweden and Copenhagen, Denmark, on March 19-23, 2003. Ancient Textiles Series 1. Oxford, 190-196.

Tzachili I., Spantidaki S., Andersson Strand E., Nosch M.-L., Cutler J. 2015. Textile Tools from Akrotiri, Thera, Greece. In: E. Andersson Strand, M.-L. Nosch (eds.), Tools, Textiles and Contexts. Investigating Textile Production in the Aegean and Eastern Mediterranean Bronze Age. Ancient Textiles Series 21. Oxford, Philadelphia, 243-246.

Ulanowska A. 2018a. Textiles in Cross-Craft Interactions. Tracing the Impact of Textile Technology on the Bronze Age Aegean Art. In: B. Gediga, A. Grossman, W. Piotrowski (eds.), Inspiracje i funkcje sztuki pradziejowej i wczesnośredniowiecznej. Biskupińskie Prace Archeologiczne 12. Prace Komisji Archeologicznej 22. Biskupin, Wrocław, 243-263.

Ulanowska A. 2018b. In Search of 'Invisible' Textile Tools and Techniques of Band Weaving in the Bronze Age Aegean. In: M. Siennicka, L. Rahmstorf, A. Ulanowska (eds.), First Textiles. The Beginnings of Textile Manufacture in Europe and the Mediterranean. Proceedings of the EAA Session Held in Istanbul (2014) and the 'First Textiles' Conference in Copenhagen (2015). Ancient Textiles Series 32. Oxford, Philadelphia, 201-212.

Ulanowska A., Siennicka M. forthcoming. The Economics of Textiles in Bronze Age Greece. In: M. S. Busana, M. Gleba, F. Meo (eds.), Textiles and Dyes in the Mediterranean. Economy and Society. Proceedings of VI PURPUREAE VESTES International Symposium (Padua, 17-20 October 2016). Zaragoza.

Van Damme T. 2012. Reviewing the Evidence for a Bronze Age Silk Industry. In: M.-L. Nosch, R. Laffineur (eds.), KOSMOS. Jewellery, Adornment and Textiles in the Aegean Bronze Age. Proceedings of the $13^{\text {th }}$ International Aegean Conference / $13^{e}$ Rencontre égéenne internationale, University of Copenhagen, Danish National Research Foundation's Centre for Textile Research, 21-26 April 2010. Aegaeum 33. Leuven, Liège, 163-169.

Vogelsang-Eastwood G. 1999. Tunakhamun's Wardrobe: Garments from the Tomb of Tutankhamun. Rotterdam.

Wace A. J. B. 1927. A Cretan Statuette in Fitzwilliam Museum - A Study in Minoan Costume. Cambridge. 


\section{Streszczenie}

\section{Ale jak je zrobiono? Więcej o tkaninach wzorzystych w Egei}

Przedmiotem artykułu jest próba oceny ikonografii wzorzystych tkanin z Egei, jako potencjalnego źródła wiedzy o technikach tkackich i technikach tworzenia wzorów w epoce brązu. Wzory z ubiorów przedstawionych w Xeste 3, Akrotiri na Therze rozpatrywane są jako studium przypadku w odniesieniu do technologii tkackiej dostępnej w epoce brązu, pozostałości tekstyliów archeologicznych z Grecji i Akrotiri oraz Europy centralnej i Śródziemnomorza, a także eksperymentalnych rekonstrukcji tkanin o wzorach opartych na ikonografii. Szczegółowa analiza wzorów na freskach i tkaninach doprowadziła do wniosku, że nie jest możliwe odtworzenie określonej techniki tkackiej na podstawie ikonografii. Jednakże cechy namalowanych wzorów sugerują, że miały one imitować prawdziwe wzory na tkaninach, oddając subtelne różnice pomiędzy nimi. Zaobserwowana dokładność pozwala także sądzić, że malarze fresków posiadali ogólną wiedzę o strukturze tkanin i jej wierne odtworzenie było przedmiotem ich szczególnej uwagi i starań. 